\title{
Managing hepatitis $C$ in general practice
}

\section{Simone I Strasser \\ Associate professor \\ AW Morrow \\ Gastroenterology and Liver \\ Centre \\ Royal Prince Alfred Hospital Sydney}

\section{Keywords}

antiviral drugs, cirrhosis

hepatitis $\mathrm{C}$

Aust Prescr 2017:40:64-9

http://dx.doi.org/10.18773/ austprescr.2017.017

First published online

7 March 2017

\section{SUMMARY}

All people with risk factors for hepatitis $\mathrm{C}$ should have a serological screening test for antihepatitis $\mathrm{C}$ antibodies.

A positive screening test should be followed by a test for hepatitis C RNA to confirm the diagnosis. The hepatitis $\mathrm{C}$ genotype and viral load should then be determined.

The severity of fibrosis should be assessed by clinical and laboratory assessment and the use of non-invasive serum scores. Transient elastography is particularly recommended when serum scores do not clearly exclude cirrhosis. Patients with a high likelihood of cirrhosis should be managed in a specialist setting.

Patients with chronic hepatitis $\mathrm{C}$ should be treated with oral direct-acting antivirals. The treatment regimen and duration should be selected according to hepatitis $\mathrm{C}$ genotype, viral load, previous treatment experience and the presence or absence of cirrhosis.

Adherence to the antiviral regimen is essential. To establish whether treatment was successful, patients should be tested for hepatitis C RNA 12 weeks after completing treatment.

\section{Introduction}

All oral, direct-acting antiviral treatments for chronic hepatitis $C$ are highly effective and well tolerated. Approximately $95 \%$ of patients will be cured with a short course of treatment. These new treatments are available on the Pharmaceutical Benefits Scheme (PBS), and have a very wide prescriber base that includes GPs. Australia therefore has the potential to markedly reduce the number of people living with hepatitis $C$ in the next 10-15 years. New cases will become rare, and rates of hepatitis $\mathrm{C}$-related advanced liver disease, liver failure, liver cancer and liver transplantation will decrease.

\section{Box When to refer patients with hepatitis $C$ to a specialist or liver clinic}

\section{Cirrhosis*}

Hepatitis B co-infection

HIV co-infection ${ }^{\dagger}$

Complex comorbidities and medication requirements

Chronic kidney disease (eGFR $<50 \mathrm{~mL} / \mathrm{min} / 1.73 \mathrm{~m}^{2}$ )

Under 18 years of age
Failure of treatment with all-oral therapy (sustained virologic response not achieved)
Ongoing evidence of liver disease despite achieving sustained virologic response
Preference not to treat hepatitis $\mathrm{C}$ in primary care

\section{eGFR estimated glomerular filtration rate}

* In rural or remote settings, access to a specialist should not be a barrier to treatment, but the patient should be discussed with a specialist and a management plan including specialist review should be developed.

+ Or refer to a GP experienced in the management of hepatitis C/HIV co-infection. with chronic hepatitis $\mathrm{C}$ are diagnosed, assessed, treated and followed up appropriately. It is essential that all medical practitioners, particularly those in primary care, have the skills to diagnose patients with hepatitis $C$ and either manage them with specialist support as needed, or refer them for specialist care (see Box).

The majority of patients do not have severe liver injury and can be managed safely and effectively in the community. However, those with cirrhosis or complex comorbidities and those who have relapsed or failed to respond to previous interferon-free treatment should be managed by an appropriate specialist. Australian consensus recommendations for the treatment of hepatitis $C$ are available, and provide guidance in many areas of hepatitis $\mathrm{C}$ care. ${ }^{2,3}$

\section{Screening, diagnosis and assessment}

It is estimated that $82 \%$ of the 227000 people living with hepatitis $C$ in Australia have been diagnosed. ${ }^{4}$ However, many of these people have either not been informed of their diagnosis or are not aware of the implications of chronic viral hepatitis. Before 2016, fewer than one in four Australians with chronic hepatitis $C$ had been treated and approximately one in five were undiagnosed. Because hepatitis $C$ is a major cause of chronic liver disease, cirrhosis and liver cancer, it is essential that all people with chronic infection are identified so that treatment can be provided.
This outcome can only be achieved if all people 
Anyone at risk of contracting a blood-borne infection should be tested for hepatitis $\mathrm{C}$, as should anyone with evidence of chronic liver disease or abnormal liver enzymes. ${ }^{2}$ Injecting drug users should be a major focus for testing as they represent approximately $80 \%$ of infected people. Other important groups include migrants from high-prevalence countries or regions such as Egypt, Pakistan, Mediterranean and eastern European countries, Africa and Asia.

Patients should be screened using a serological test for anti-hepatitis $\mathrm{C}$ antibodies. If screening is positive, diagnosis requires confirmation of infection using a polymerase chain reaction (PCR)-based assay to detect hepatitis C RNA. If viral RNA is present, genotype and viral load testing should be performed to determine the appropriate treatment regimen and duration. The Figure shows a simplified schema for the management of patients with chronic hepatitis $C{ }^{3}$ Patients who have antibodies to hepatitis $C$ but test negative for viral RNA (confirmed on two occasions at least one month apart) do not have chronic hepatitis $\mathrm{C}$. They may have spontaneously cleared infection, been previously successfully treated, or have a false positive antibody result.

All patients should be assessed for liver disease and comorbidities. Having a history of excessive alcohol intake, being overweight or obese, and having type 2 diabetes or other liver disease significantly increase the chance that an individual has advanced fibrosis or cirrhosis. Laboratory testing should include assessment of renal function, blood glucose, other blood-borne infections such as HIV and hepatitis B, liver enzymes and full blood count. An elevated aspartate aminotransferase (AST) and low platelet count are suggestive of advanced fibrosis or cirrhosis.

Fibrosis assessment is essential before starting antiviral treatment as the results can change after treatment and people at risk of long-term complications such as hepatocellular carcinoma can be missed. Many people with a low risk of advanced fibrosis, such as younger patients with a short duration of infection or people without a history of excessive alcohol intake or metabolic risk factors, can be assessed using simple validated serumbased scores such as the APRI score (AST to Platelet Ratio Index $)^{5}$ and Hepascore. ${ }^{6}$ A low score excludes cirrhosis, and patients with a high score (e.g. an APRI score $\geq 1$ ) have an increased likelihood of cirrhosis and should be assessed further.

Patients requiring more accurate assessment of liver fibrosis than can be determined by serum markers may benefit from transient elastography (Fibroscan). Fixed machines in liver clinics, or portable machines in community settings, offer rapid, accurate and non- invasive assessment of fibrosis. Access to transient elastography is increasing and can generally be arranged through the local health district or other providers. As with serum markers, a low score is very accurate for excluding cirrhosis, but a median liver stiffness of at least $12.5 \mathrm{kPa}$ is associated with a significantly higher chance of cirrhosis. These patients require specialist review and long-term surveillance for hepatocellular carcinoma and other liver disease complications.

\section{Antiviral treatment of hepatitis C}

Multiple oral regimens are currently available on the PBS. They may be prescribed by a medical practitioner experienced in the treatment of chronic hepatitis $\mathrm{C}$ infection, or in consultation with a gastroenterologist, hepatologist or infectious diseases physician.

\section{Fig. Essential steps in treating hepatitis $\mathrm{C}$ in primary care}

1

Test for hepatitis $C$ virus genotype and viral load, full blood count, urea, electrolytes and creatinine, blood glucose, liver function, and hepatitis B. Also test for HIV and immunity to hepatitis A.

Exclude cirrhosis - refer patients with cirrhosis, renal failure, hepatitis B

2 positive, and HIV co-infection (unless experienced in the management of hepatitis C/HIV co-infection).

Select appropriate regimen ( 8 or 12 weeks) according to genotype. Identify

3 any potential barriers to adherence and adopt a patient-centred approach to ensure adherence.

4 Check for drug-drug interactions (http://hep-druginteractions.org).

- Check for sustained virologic response 12 weeks after the end of treatment
by testing for hepatitis $\mathrm{C}$ virus RNA.
- Check full blood count and liver function.
- Check full blood count and liver function.

- If sustained virologic response and normal tests, no further follow-up is
required.
- If sustained virologic response, and abnormal tests, assess further.
- If no sustained virologic response, refer to a specialist for further management.
- If sustained virologic response, and ongoing risk of reinfection, check
hepatitis C RNA every 6-12 months.

Source: Reference 3 
As this therapeutic area is evolving rapidly, it is important that prescribers keep abreast of changes or maintain close links with specialists, to ensure patients are given the most appropriate treatments. It is anticipated that, in the next 12 months, new treatments will be approved that are equally effective across all hepatitis $C$ genotypes. It will therefore become less important to know what genotype the patient has before treatment. In the meantime, it is essential that the hepatitis $C$ genotype is determined, as not all currently approved regimens are effective or available for all genotypes.

Table 1 shows treatment regimens currently approved and available on the PBS. Additional regimens are approved but not recommended as they provide inferior efficacy or tolerability. It should be noted that a short, eight-week course of sofosbuvir/ledipasvir fixed- dose combination is appropriate for treatment-naïve patients with genotype 1 infection, no cirrhosis and a viral load less than $6 \times 10^{6} \mathrm{IU} / \mathrm{mL}$. Most other patients require 12 weeks of treatment, while some patients with cirrhosis and previous treatment failure (who will generally be under specialist care) require 24 weeks of treatment.

Key features of the currently available regimens are shown in Table 2. Each antiviral drug must be used in combination with at least one additional antiviral drug to avoid drug resistance. These antivirals are directed at discrete intracellular targets of hepatitis $C$ including the NS5B polymerase involved in replication (sofosbuvir, dasabuvir), the NS3/4A protease involved in protein production (grazoprevir, paritaprevir), and the NS5A domain involved in assembly and release (daclatasvir, ledipasvir, elbasvir, ombitasvir and velpatasvir). Some regimens include ribavirin.

\section{Table 1 PBS-listed oral treatments for chronic hepatitis C}

\begin{tabular}{|c|c|c|c|c|c|c|}
\hline \multirow[t]{3}{*}{ Daily drug regimen } & \multirow[t]{3}{*}{ Brand name } & \multirow[t]{3}{*}{ Genotype } & \multicolumn{4}{|c|}{$\begin{array}{l}\text { Treatment duration } \\
\text { (depending on patient characteristics) }\end{array}$} \\
\hline & & & \multicolumn{2}{|c|}{ No cirrhosis } & \multicolumn{2}{|c|}{ Cirrhosis* } \\
\hline & & & $\begin{array}{l}\text { Treatment- } \\
\text { naïve }\end{array}$ & $\begin{array}{l}\text { Treatment- } \\
\text { experienced }^{\dagger}\end{array}$ & $\begin{array}{l}\text { Treatment- } \\
\text { naïve }\end{array}$ & $\begin{array}{l}\text { Treatment- } \\
\text { experienced }\end{array}$ \\
\hline $\begin{array}{l}\text { Sofosbuvir } 400 \text { mg/ledipasvir } 90 \text { mg } \\
\text { fixed-dose combination }\end{array}$ & Harvoni & $1 \mathrm{a}$ or $1 \mathrm{~b}$ & $\begin{array}{l}8 \text { weeks } \ddagger \\
\text { or } \\
12 \text { weeks }\end{array}$ & 12 weeks & 12 weeks & 24 weeks \\
\hline $\begin{array}{l}\text { Sofosbuvir } 400 \mathrm{mg}+\text { daclatasvir } 60 \mathrm{mg} \\
( \pm \text { ribavirin) } \S\end{array}$ & $\begin{array}{l}\text { Sovaldi + } \\
\text { Daklinza }\end{array}$ & 1a or 1b & 12 weeks & $\begin{array}{l}12 \text { weeks } \\
\text { or } \\
24 \text { weeks }\end{array}$ & $\begin{array}{l}12 \text { weeks } \\
\text { (+ ribavirin) } \\
\text { or } \\
24 \text { weeks } \\
\text { (no ribavirin) }\end{array}$ & $\begin{array}{l}12 \text { weeks } \\
\text { (+ ribavirin) } \\
\text { or } \\
24 \text { weeks } \\
\text { (no ribavirin) }\end{array}$ \\
\hline $\begin{array}{l}\text { Paritaprevir } 150 \text { mg/ritonavir } 100 \mathrm{mg} / \\
\text { ombitasvir } 25 \mathrm{mg} \text { fixed-dose combination } \\
\text { + dasabuvir } 250 \mathrm{mg} \text { twice daily ( } \pm \text { ribavirin) }\end{array}$ & $\begin{array}{l}\text { Viekira Pak or } \\
\text { Viekira Pak-RBV }\end{array}$ & 1a only & $\begin{array}{l}12 \text { weeks } \\
\text { (+ ribavirin) }\end{array}$ & $\begin{array}{l}12 \text { weeks } \\
\text { (+ ribavirin) }\end{array}$ & $\begin{array}{l}12 \text { weeks } \\
\text { (+ ribavirin) }\end{array}$ & $\begin{array}{l}12 \text { weeks or } \\
24 \text { weeks } \\
\text { (+ ribavirin) }\end{array}$ \\
\hline & & 1b only & 12 weeks & 12 weeks & 12 weeks & 12 weeks \\
\hline $\begin{array}{l}\text { Elbasvir } 50 \text { mg/grazoprevir } 100 \mathrm{mg} \text { fixed-dose } \\
\text { combination ( } \pm \text { ribavirin) } \S\end{array}$ & Zepatier & 1a or 1b, 4 & 12 weeks & $\begin{array}{l}16 \text { weeks } \\
\text { ( } \pm \text { ribavirin) }\end{array}$ & 12 weeks & $\begin{array}{l}16 \text { weeks } \\
\text { ( } \pm \text { ribavirin) }\end{array}$ \\
\hline Sofosbuvir $400 \mathrm{mg}+$ ribavirin $\S$ & Sovaldi & 2 & 12 weeks & 12 weeks & 12 weeks & 12 weeks \\
\hline $\begin{array}{l}\text { Sofosbuvir } 400 \mathrm{mg}+\text { daclatasvir } 60 \mathrm{mg} \\
( \pm \text { ribavirin) } \S\end{array}$ & $\begin{array}{l}\text { Sovaldi + } \\
\text { Daklinza }\end{array}$ & 3 & 12 weeks & 12 weeks & $\begin{array}{l}12 \text { or } 24 \text { weeks } \\
\text { ( } \pm \text { ribavirin) }\end{array}$ & $\begin{array}{l}12 \text { or } 24 \text { weeks } \\
\text { ( } \pm \text { ribavirin) }\end{array}$ \\
\hline $\begin{array}{l}\text { Sofosbuvir } 400 \text { mg/velpatasvir } 100 \mathrm{mg} \\
\text { fixed-dose combination\# ( } \pm \text { ribavirin }) \S\end{array}$ & Epclusa & $1-6$ & 12 weeks & 12 weeks & 12 weeks & 12 weeks \\
\hline
\end{tabular}

PBS Pharmaceutical Benefits Scheme

* Patients with cirrhosis should be managed in a specialist setting. An interferon-free regimen is not currently available for patients with genotype 6 .

+ Treatment-experienced usually refers to failure to clear virus on pegylated interferon plus ribavirin.

$\ddagger$ Eight weeks may be considered if hepatitis C RNA is less than $6 \times 10^{6} \mathrm{IU} / \mathrm{mL}$.

$\S$ Ribavirin dosing is weight-based. Recommended dose is $1000 \mathrm{mg}$ daily for people weighing less than $75 \mathrm{~kg}$ and $1200 \mathrm{mg}$ daily for people weighing at least $75 \mathrm{~kg}$.

\# Currently (March 2017) recommended by the Pharmaceutical Benefits Advisory Committee for PBS listing.

- Adding ribavirin is recommended in all patients with decompensated cirrhosis and can be considered in patients with compensated cirrhosis who have genotype 3 infection. 


\section{Table 2 Current hepatitis C antiviral treatments}

\begin{tabular}{|c|c|c|c|c|}
\hline Drug & Mechanism of action & Genotype coverage & $\begin{array}{l}\text { Key drug interactions and } \\
\text { recommendations }\end{array}$ & $\begin{array}{l}\text { Contraindications and } \\
\text { warnings }{ }^{*}\end{array}$ \\
\hline \multirow[t]{2}{*}{ Sofosbuvir } & $\begin{array}{l}\text { NS5B RNA polymerase } \\
\text { inhibitor (chain terminator) }\end{array}$ & $\begin{array}{l}\text { Pan-genotypic, must } \\
\text { be used in combination }\end{array}$ & $\begin{array}{l}\text { Phenytoin should not be } \\
\text { co-prescribed. }\end{array}$ & \multirow{9}{*}{$\begin{array}{l}\text { Sofosbuvir concentrations } \\
\text { increase in renal impairment. } \\
\text { Dose adjustment not necessary } \\
\text { in mild and moderate } \\
\text { impairment. } \\
\text { Safety has not been established } \\
\text { when eGFR }<30 \mathrm{~mL} / \mathrm{min} / 1.73 \mathrm{~m}^{2} \text {. } \\
\text { If these drugs are the only } \\
\text { option, closer monitoring for } \\
\text { adverse effects is advised. }\end{array}$} \\
\hline & & with another drug. & $\begin{array}{l}\text { Not recommended with } \\
\text { amiodarone as symptomatic } \\
\text { bradycardia has been reported. }\end{array}$ & \\
\hline \multirow[t]{4}{*}{$\begin{array}{l}\text { Sofosbuvir/ } \\
\text { ledipasvir }\end{array}$} & \multirow[t]{4}{*}{$\begin{array}{l}\text { NS5A inhibitor + polymerase } \\
\text { inhibitor }\end{array}$} & \multirow{4}{*}{$\begin{array}{l}\text { Approved only for } \\
\text { genotype } 1 \text { (effective } \\
\text { also in genotypes } 4,6 \text { ). }\end{array}$} & $\begin{array}{l}\text { Phenytoin should not be } \\
\text { co-prescribed. }\end{array}$ & \\
\hline & & & $\begin{array}{l}\text { Not recommended with } \\
\text { amiodarone as symptomatic } \\
\text { bradycardia has been reported. }\end{array}$ & \\
\hline & & & $\begin{array}{l}\text { Absorption is reduced with } \\
\text { proton pump inhibitors. }\end{array}$ & \\
\hline & & & $\begin{array}{l}\text { Some statins may require dose } \\
\text { reduction - rosuvastatin should } \\
\text { not be co-prescribed. }\end{array}$ & \\
\hline \multirow{3}{*}{$\begin{array}{l}\text { Sofosbuvir/ } \\
\text { velpatasvir }\end{array}$} & \multirow{3}{*}{$\begin{array}{l}\text { NS5B RNA polymerase } \\
\text { inhibitor + NS5A inhibitor }\end{array}$} & \multirow[t]{3}{*}{ Genotypes 1-6 } & Co-administration of potent & \\
\hline & & & $\begin{array}{l}\text { CYP2B6, CYP2C8 and CYP3A4 } \\
\text { inducers is not recommended. }\end{array}$ & \\
\hline & & & $\begin{array}{l}\text { Not recommended with } \\
\text { amiodarone as symptomatic } \\
\text { bradycardia has been reported. }\end{array}$ & \\
\hline
\end{tabular}

\section{Daclatasvir NS5A inhibitor}

Approved only for genotypes 1 and 3 but pan-genotypic. Always used with sofosbuvir. protease inhibitor + NS5A ritonavir/ ombitasvir + dasabuvir inhibitor + non-nucleoside polymerase inhibitor

\section{Genotype 1 only}

Phenytoin should not be co-prescribed.

Some drug-drug interactions occur.

Some statins may require dose reduction.

\section{Phenytoin should not be} co-prescribed.

Multiple drug-drug interactions occur - ritonavir is a potent inhibitor of CYP3A4.

Some statins may require dose reduction - simvastatin or atorvastatin should not be co-prescribed.

\section{Elbasvir/}

grazoprevir

\section{NS5A inhibitor +}

NS3/4A protease inhibitor

\section{Genotypes 1 and 4}

\section{Phenytoin should not be co-prescribed.}

Multiple drug-drug interactions occur.

Some statins may require dose reduction.
Can be used in renal failure.

Contraindicated in liver failure.
Can be used in renal failure.

Contraindicated in liver failure.
Contraindicated in pregnancy.

Dose adjustment needed in renal impairment.

CYP cytochrome P450

eGFR estimated glomerular filtration rate

* Antiviral treatments should not be administered during pregnancy or lactation. 


\section{Tolerability and drug interactions}

In general, antiviral regimens are well tolerated, however there are some nuances. All regimens can potentially interact with concomitant drugs, and it is strongly recommended that potential interactions be assessed and managed. A full review of all prescription, over-the-counter and complementary medicines is essential. The use of a web-based interaction checker is invaluable. ${ }^{8}$ Because the hepatitis $C$ treatment is relatively short, consider withholding interacting drugs, for example statins (see Table 2).

Sofosbuvir is currently not recommended for patients with an estimated glomerular filtration rate less than $30 \mathrm{~mL} / \mathrm{min} / 1.73 \mathrm{~m}^{2}$. Protease inhibitors are contraindicated in patients with decompensated cirrhosis. These patients should be managed by a specialist, rather than by community prescribers. Also those co-infected with hepatitis B should be managed by a specialist as there are concerns about hepatitis $B$ reactivation during hepatitis $C$ treatment. Because of reports of severe hepatitis B reactivation, the US Food and Drug Administration and the Australian Consensus Statement (January 2017 update) ${ }^{2}$ recommend screening all patients for hepatitis $B$ before starting antiviral treatment. The recommended tests are for HBsAg, anti-HBc and anti-HBs. Patients who are HBsAg positive require either concomitant antiviral treatment for hepatitis $\mathrm{B}$, or close monitoring of alanine aminotransferase (ALT) and hepatitis B DNA during and after treatment.

Ribavirin is a teratogen and both men and women must ensure two forms of contraception and avoid pregnancy until at least six months after completion of a ribavirin-containing regimen.

\section{Treatment adherence}

It is obviously important that patients adhere to the prescribed treatment schedule and any barriers to adherence should be identified before treatment begins. Information regarding the number of tablets to be taken and at what time of day, advice on what to do if a dose is missed, and how to obtain medicines from the pharmacy, should all be provided to the patient. Patients should be informed that hepatitis $C$ medicines are not readily available from most community pharmacies for same-day supply. If patients are admitted to hospital, ensure they take their medicines with them to avoid missing doses. Some patients may benefit from regular phone calls or check-ups to ensure adherence. Adherence guidelines ${ }^{9}$ and a quick reference guide ${ }^{10}$ have been developed by the Australian Hepatology Association and emphasise the need for a patientcentred approach.

\section{Post-treatment follow-up}

While little, if any, blood test monitoring is required while patients are on antiviral treatment (although haemoglobin should be regularly monitored when ribavirin is used), it is essential that patients undergo a blood test for viral RNA 12 weeks after completing a course of therapy. This is to ensure that treatment has been successful and there is no evidence of ongoing liver disease. Undetectable hepatitis C RNA at 12 weeks after treatment (sustained virologic response - SVR12) is highly likely to be durable. Patients who did not have cirrhosis before treatment, achieve SVR12 and have a complete normalisation of liver enzymes (regarded as an ALT of $\leq 30 \mathrm{U} / \mathrm{L}$ in men and $\leq 19 \mathrm{U} / \mathrm{L}$ in women) require no further follow-up.

Successful clearance of hepatitis $C$ does not protect against reinfection, and patients with ongoing risk factors require regular testing. In this situation, they should be tested for hepatitis C RNA (PCR) every 6-12 months. Serology for hepatitis $C$ antibodies has no role in ongoing monitoring as it remains positive in all individuals who have ever had exposure to hepatitis $\mathrm{C}$.

Patients who fail to achieve a sustained virologic response or do not have normalisation of liver enzymes require further assessment. In those who take a complete course of therapy, this is generally due to the emergence of drug-resistant variants, most commonly to the NS5A component of the regimen. These variants may have been pre-existing. Nonadherence or an incomplete course of therapy could also result in post-treatment failure. Patients with detectable hepatitis C RNA in post-treatment followup should be referred for specialist consultation to determine the most appropriate re-treatment regimen. When liver enzymes fail to normalise, additional causes of liver disease should be sought. These include nonalcoholic fatty liver disease (associated with type 2 diabetes and being overweight or obese), alcoholic liver disease due to ongoing excessive alcohol intake, genetic haemochromatosis and autoimmune liver disease. Patients with comorbidities that increase their risk for chronic liver disease should be monitored and managed long term despite viral clearance.

Patients with cirrhosis before treatment require long-term surveillance for complications regardless of whether their liver enzymes or liver stiffness (assessed by transient elastography) normalise or reduce. Six-monthly liver ultrasound examinations are indicated in these patients, and in patients with advanced fibrosis and ongoing risk factors for liver disease (e.g. metabolic syndrome or excessive alcohol intake). New liver nodules that might represent early hepatocellular carcinoma may be amenable to curative treatment, whereas late presentation with symptomatic 
disease is usually associated with a poor prognosis. Many patients at risk for hepatocellular carcinoma will prefer to be monitored in the community rather than in specialist centres. Clinicians should be aware that hepatocellular carcinoma may develop many years after viral eradication and ensure ongoing monitoring.

\section{Conclusion}

Community-based management is essential to reduce hepatitis $\mathrm{C}$ in Australia. Broad access to short-duration, well-tolerated treatments provides this opportunity. Despite its relative simplicity, treatment may still be challenging for some individuals, however benefits such as reduced transmission rates and improved clinical outcomes mean that all clinicians should identify a means to deliver these treatments. Support from an experienced nurse, pharmacist and specialist should be sought where necessary. Future advances in antiviral treatments will make management in the community even simpler.

Simone Strasser has received honoraria and travel support for advisory boards and speaking from Gilead, AbbVie, Bristol-Myers Squibb and MSD. She is honorary treasurer of the Gastroenterological Society of Australia.

\section{REFERENCES}

1. Sievert W, Razavi H, Estes C, Thompson AJ, Zekry A Roberts SK, et al. Enhanced antiviral treatment efficacy and uptake in preventing the rising burden of hepatitis C-related liver disease and costs in Australia. J Gastroenterol Hepatol 2014;29 Suppl 1:1-9. http://dx.doi.org/10.1111/jgh.12677

2. Hepatitis C Virus Infection Consensus Statement Working Group. Australian recommendations for the management of hepatitis C virus infection: a consensus statement (January 2017) Melbourne: Gastroenterological Society of Australia; 2017. www.hepcguidelines.org.au [cited 2017 Feb 21]

3. Gastroenterological Society of Australia. Hepatitis C treatment. 2017. www.gesa.org.au/resources/hepatitis-ctreatment [cited 2017 Feb 21]

4. The Kirby Institute. Hepatitis B and C in Australia Annual Surveillance Report Supplement 2016. Sydney: The Kirby Institute, UNSW Australia; 2016. http://kirby.unsw.edu.au/ surveillance/hepatitis-b-and-c-australia-annual-surveillancereport-supplement-2016-0 [cited 2017 Feb 21]

5. Hepatitis C online. AST to Platelet Ratio Index (APRI) Calculator. 2016. www.hepatitisc.uw.edu/page/clinicalcalculators/apri [cited 2017 Feb 21]

6. Adams LA, Bulsara M, Rossi E, DeBoer B, Speers D, George J, et al. Hepascore: an accurate validated predictor of liver fibrosis in chronic hepatitis $\mathrm{C}$ infection. Clin Chem 2005;51:1867-73. http://dx.doi.org/10.1373/ clinchem.2005.048389
7. Kemp W, Levy M, Weltman M, Lubel J; Australian Liver Association (ALA). Australian Liver Association (ALA) expert consensus recommendations for the use of transient elastography in chronic viral hepatitis. J Gastroenterol Hepatol 2015;30:453-62. http://dx.doi.org/ 10.1111/jgh.12865

8. HEP Drug Interactions. HEP drug interaction checker. Liverpool: University of Liverpool; 2016 www.hep-druginteractions.org [cited 2017 Feb 21]

9. Richmond JA, Sheppard-Law S, Mason S, Warner SL. The Australasian Hepatology Association consensus guidelines for the provision of adherence support to patients with hepatitis $C$ on direct acting antivirals. Patient Prefer Adherence 2016;10:2479-89. http://dx.doi.org/10.2147/PPA.S117757

10. Quick reference guide: Highlights from the Australasian Hepatology Association (AHA) consensus guidelines for the provision of adherence support to patients with hepatitis $C$ on direct acting antivirals. Brisbane: Australasian Hepatology Association; 2016. http://hepatologyassociation.com.au/ wp-content/uploads/2016/11/Quick-Reference-to-the-AHAConsensus-Guidelines-for-Adherence-Support-for-Patientson-DAAs-v5.pdf [cited 2017 Feb 21] 